\title{
HSD17B7 Gene
}

National Cancer Institute

\section{Source}

National Cancer Institute. HSD17B7 Gene. NCI Thesaurus. Code C24478.

This gene is involved in regulation of the biological potency of certain steroids. 